\title{
Som å ta av seg verktøybeltet: Kontraster og metaforer i overgangen fra fagarbeid til yrkesfaglærerutdanning
}

\author{
(Leaving the tool belt behind: Contrasts and metaphors in the \\ transition from vocational work to vocational teacher education)
}

\author{
Nora Kolkin Sarastuen \\ OsloMet - Storbyuniversitetet, Norge (norako@oslomet.no)
}

\begin{abstract}
This article explores the transition from work to higher education and how vocational teacher students talk about the transition from occupational work to vocational teacher education. Previous research has identified students' experiences of coherence in higher education as a challenge, and in this article the aspect of coherence that explores the contrasts and conflicts between vocational teacher students' past experiences as occupational workers and experiences in vocational teacher education (biographic coherence) is explored. It is a qualitative study with participant observations and focus group interviews with Norwegian vocational teacher students at their second year of a bachelor's degree programme to become vocational teachers. The analysis shows that students use metaphors and contrasts when they talk about the transition from occupational work to higher education. The metaphors and contrasts elicit an emotional aspect of the transition from work to education, and how students use their previous experiences from occupational work to give meaning to experiences in education.
\end{abstract}

Keywords: vocational teacher education, higher education, transitions, coherence, contrasts 


\section{Innledning}

Yrkesfaglærerutdanningen (YFL) plasserer yrkesfaglærerstudenter i spenningsfeltet mellom håndverks- og utdanningstradisjonen - to forskjellige og ofte motsetningsfylte tenke- og handlemåter som YFL skal utdanne dem til å håndtere (Billett, 2011; Colley, James, Diment \& Tedder, 2003; Eraut, 2004; Page, 2013; Robson, Bailey \& Larkin, 2004; Tapini \& Salonen, 2018; Davis, Van den Bossche, Gijbels \& Garrido, 2016). Sentralt for yrkesfaglærerens kompetanse er evnen til å skape sammenhenger mellom arbeidsliv og utdanning (Tapini \& Salonen, 2018). Det vil derfor være særlig viktig å utdanne aktører som ser sammenhengene. Sammenhenger har forskjeller og en tydeliggjøring av kontraster kan forstås som et premiss for å skape kobling mellom to motsetningsfylte arenaer. Denne studien bidrar til økt kunnskap om norske yrkesfaglærerstudenters opplevelse av kontraster i utdanningen.

Å skape meningsfulle og sammenhengende overganger for studenter - koherens - er identifisert som én særlig utfordring i utdanningssammenheng og knyttes for eksempel til samspillet mellom teori og praksis i profesjonsutdanninger, læring i høyere utdanning og/eller utvikling av profesjonell identitet (Brandt \& Hatlevik, 2003; Duch, 2016; Duch \& Andreasen, 2017; Hatlevik \& Havnes, 2017; Heggen \& Smeby, 2012; Smeby \& Heggen, 2014). Heggen og Raaen (2014, s. 4) påpeker at koherens blant annet handler om "integrering av ulike element $\mathrm{i}$ ein kvalifiseringsprosess". I utdanningen møter studentene på utfordringer med å knytte tidligere erfaringer fra fagarbeid til det som skjer i utdanningen (og senere som yrkesfaglærere). Erfaringene kan ha sammenheng med eller stå i kontrast til innholdet i utdanningen og koherens åpner opp for å utforske kontraster i en overgang; "Koherens må derfor ikkje handle om å gi inntrykk av enkle samanhengar, men at dei reelle motsetningane blir eksponerte slik at dei kan bli vurderte" (Heggen \& Smeby, 2012, s. 12). I denne artikkelen rettes fokuset mot det aspektet av koherens som handler om kontrastene, konfliktene og motsetningene og undersøker hva som kjennetegner yrkesfaglærerstudentenes opplevelse av kontrastene mellom utdanning og deres tidligere erfaringer som fagarbeidere.

Tapani og Salonen (2018) bemerker stor variasjon i holdningen til kvalifisering av yrkesfaglærere i de nordiske landene. Dette kommer for eksempel til uttrykk gjennom den relativt store variasjonen i yrkesfaglærere uten utdanning: Danmark, 8\%, Finnland 20\%, Norge 28\% og Sverige 29\% (Tapini \& Salonen, 2018). Rekrutering varierer også; det er for eksempel lettere for fagarbeidere å få seg lærerjobb i Norge, Sverige og Finland uten utdanning sammenliknet med Danmark. Til tross for ulikheter peker Loeb og Gustavsson (2018) på at mange av utfordringene går på tvers i de nordiske landene og at utdanning av yrkesfaglærere er jevnt over lite studert.

For å heve kompetansen blant yrkesfaglærere i Norge, samt møte kravene fra Reform 94 i videregående opplæring, ble utdanning av yrkesfaglærere etablert 
som en bachelorutdanning i 2000 (Rokkones, Landro \& Utvær, 2018; St.meld. 48, 1996-1997). Reform 94 førte til store endringer i fag- og yrkesopplæring på videregåendenivå, med blant annet færre og bredere grunnkurs, og dette skapte et behov for yrkesfaglærere med større breddekompetanse (Brandt \& Hatlevik, 2003). YFL bygger på fag-/svennebrev eller tilsvarende utdanning på videregåendenivå i tillegg til minst 2 års yrkesfaglig praksis. De fleste yrkesfaglærerstudentene er godt voksne med lang erfaring fra yrkeslivet, og har ett eller flere fagbrev. En fagarbeider kan ansettes på vilkår om påbegynt utdanning innen to år og mange av studentene jobber derfor som lærere ved siden av studiet. Kravet er relativt nytt og studentene har slik sett ulike erfaringer fra å jobbe som lærere; noen har jobbet som lærere i flere år. I denne studien rettes fokuset mot hvordan studentene opplever møtet med utdanningen, dette utelukker ikke erfaringer fra læreryrket ettersom praksisutplassering inngår som en del av utdanningsløpet. YFL gir 180 studiepoeng og kvalifiserer til arbeid på ungdomstrinnet og i videregående opplæring. Den beskrives som en integrert utdanning og omfatter profesjonsfaget (pedagogikk og didaktikk), yrkesfag (yrkesfaglig bredde og dybde) og praksis (i skoler) (Rokkones, Landro \& Utvær, 2018). I studien er fokuset avgrenset til profesjonsfaget.

Historisk sett er høyere utdanning en relativt ny mekanisme i overgang fra et yrke til et annet generelt og i kvalifiseringen til yrkesfaglærer spesielt. YFL utgjør således en særegen arena som tilfører andre og nye prosesser i en slik overgang enn for eksempel allmennlærerutdanningen. Målet med studien er økt forståelse for prosessene og utfordringene som reiser seg i kjølevannet av lærerutdanning som overgang fra yrke til arbeid i fag- og yrkesopplæring, med særlig fokus på motsetninger og kontraster. Studien bidrar til å eksponere motsetninger slik de kommer til syne i utdanningen slik at de kan bli vurdert og forstått. Forskningsspørsmålene er som følger:

- Hva kjennetegner yrkesfaglærerstudenters opplevelse av YFL som overgang fra fagarbeideryrket til yrkesfaglærerutdanning?

- På hvilke måter beskriver studentene kontrastene mellom utdanningen og deres tidligere erfaringer som fagarbeidere?

Videre i artikkelen presenteres tidligere forskning etterfulgt av en gjennomgang av teoretiske perspektiv, deretter redegjøres det for artikkelens metodiske tilnærming, før presentasjonen av funnene. Artikkelen avsluttes med en diskusjon og konkluderer med mulige implikasjoner for yrkesfaglærerutdanningen. 


\section{YFL som kvalifiseringsarena}

Som kvalifiseringsarena skal yrkesfaglærerutdanningen være rotfestet i både håndverkstradisjonen og utdanningstradisjonen og således utdanne yrkesfaglærere som blir kompetent $\mathrm{i}$, og har god kjennskap til, begge disse arenaene (Brandt \& Hatlevik, 2003; Fejes \& Köpsén, 2014). Å skape helhet og sammenheng mellom profesjonsfag, yrkesfag og praksis (i skole) pekes på som utfordrende i yrkesfaglærerutdanningen, så vel som i andre profesjonsutdanninger (Heggen \& Raaen, 2014; Rokkones, Landro \& Utvær, 2018). Duch og Andreasen (2017) har undersøkt hvordan yrkesfaglærerstudenter forholder seg til spørsmål om koherens, kontraster og likheter i utdanningsløpet. De viser blant annet til en mangel på opplevelse av sammenheng, men at denne ble skapt i studiet gjennom for eksempel oppgaver i vitenskapsteori. Erfaringer i utdanningen kan altså bidra til å skape opplevelsen av sammenheng. Samtidig var forskjeller og konflikter mellom kontekstene også en drivkraft for læring (Duch \& Andreasen, 2017).

Yrkesfaglærere rekrutteres på bakgrunn av sin fagbakgrunn og tidligere forskning trekker frem viktigheten av å forstå studentenes bakgrunn som fagarbeidere (Alvunger \& Johansson, 2018; Köpsén, 2014; Sarastuen, 2019). Erfaringer fra arbeidslivet er viktig for hvordan studentene møter utdanningen og anses som en ressurs YFL ikke kan kompensere for (Alvunger \& Johansson, 2018; Brandt \& Hatlevik, 2003). Kunnskaper og ferdigheter fra fagarbeid er dermed en av forutsetningene for yrkesfaglærerens kompetanse. Heggen og Raaen (2014) trekker i tillegg frem at utvikling av profesjonell kunnskapsbase fordrer en viderebygging på allerede tilegnede erfaringer og kunnskaper.

Arbeidslivets hurtige endringer og økende kompleksitet utfordrer kvalifiseringen av fremtidige fagarbeidere og dermed yrkesfaglæreres kompetanse (Wenström, Uusiaitti \& Määttä, 2018; Wheelahan, 2015). Tapani og Salonen (2019) hevder at yrkesfaglærerens evne til å binde sammen og skape sammenhenger mellom arbeidsliv og utdanning blir stadig viktigere. A håndtere den doble faglige tilhørigheten er særlig utfordrende og fagarbeiderkompetansen ser ut for å være mer fremtredende enn identiteten som lærer (Esmond \& Wood, 2017; Green, 2015). Nylund og Gudmundson (2017) viser til en tendens i tidligere forskning, hvor yrkesfaglærere ikke erkjenner at det kreves en særskilt kompetanse ut over erfaringer fra arbeidslivet og "sunn fornuft", og at yrkesfaglærere anser seg selv mer som arbeidsledere enn lærere. Fagarbeidere tillegger altså kunnskaper og ferdigheter fra fagarbeid stor verdi (Sarastuen, 2019). Samtidig har balansen mellom fagarbeideridentiteten og læreridentiteten implikasjoner for hvor forberedt yrkesfaglærere er i undervisning (Fejes \& Köpsén, 2014). Fagarbeidere skal altså utdannes til å utvikle en hybrididentitet - en identitet bestående av fagarbeiderog læreridentitet (Farnsworth \& Higham, 2012). For å stå i spenningsfeltet mellom to relativt motsetningsfylte arenaer kan det være viktig å løfte frem kontrastene mellom arenaene. 
Lærerutdanning er sentral for utviklingen av kompetansen til å binde sammen fagarbeiderkunnskaper- og ferdigheter med praksisen som lærer (Fejes \& Köpsén, 2014). I YFL møter studentene en diskurs som stiller opp et annet "objekt" enn studentene har forholdt seg til som fagarbeidere blant annet gjennom at resultatet eller målet og aktørene differerer. Gjennom YFL kan altså studentene bevege seg inn i lærerprofesjonsdiskursen. Studentene må blant annet reflektere over hvordan teoretisk kunnskap understøtter fagarbeidet, og hvordan praktiske og kontekstuelle elementer av arbeidslivkunnskap rammes inn i en undervisning-læring-situasjon (Alvunger \& Johansson, 2018). Utvikling av teoretiske kunnskaper, samt pedagogisk forståelse, er avgjørende for å utdanne kompetente lærere; "and not merely trainers who have a repertoire of procedures that they apply in different circumstances" (Wheelahan, 2015, s. 753).

Utdanning som utviklingsmekanisme kan igangsette identitetsutvikling og dermed oppstår det utfordringer knyttet til endringer av identitet (Chan, 2012; Duch, 2016). Dette kan skape sårbare aktører, og i en studie av Duch (2016) brukte studentene ord som "forandret identitet", "identitetskrise" og "transformasjon" for å forklare endringen. Som overgang er utdanningen altså rammen for, og en igangsetter av, utviklings- og endringsprosesser som studentene må håndtere. Et viktig spørsmål blir derfor hva som skal til for å skape meningsfulle og sammenhengende overganger (Heggen \& Raaen, 2014) - noe som kanskje er særlig viktig for å møte studenter som sårbare aktører.

\section{Teoretiske perspektiv}

Koherens knyttes til meningsdanning hvor erfaringer ses i forhold til, og forstås i lys av, hverandre (Hatlevik \& Havnes, 2017; Smeby \& Heggen, 2014). Smeby og Heggen (2014) påpeker at begrepet kan forstås som en motsetning til noe fragmentert, samtidig må det ikke forveksles med konsistens - når noe er konsistent innebærer det et fravær av motsigelser eller motsetninger. Koherens, på den andre siden, relateres til noe som er sammenhengende og utelukker derfor ikke konflikter og spenninger (Smeby \& Heggen, 2014). I denne artikkelen rettes fokuset mot det aspektet av koherens som synliggjør konflikter og kontraster.

Det skilles gjerne mellom biografisk-, program-, og overgangskoherens (Heggen \& Smeby, 2012). I artikkelen utforskes det aspektet av biografisk koherens som handler om kontraster, motsetninger og forskjeller. Biografisk koherens refererer til sammenhengen mellom utdanning og kunnskaper og erfaringer ervervet forut for påbegynt studieløp (Smeby \& Heggen, 2014). For yrkesfaglærerstudentene kan dette være erfaringer fra fagbrevutdanning som yrkesfagelev, samt erfaringer og kunnskaper tilegnet gjennom fagarbeid. Her fokuseres det på erfaringer fra yrkeslivet. Forholdet mellom tidligere erfaringer og læring i utdanningen beskrives som komplekst, med individuelle variasjoner avhengig av for eksempel betydningen av tidligere erfaringer (Smeby \& Heggen, 2014). 
Tidligere erfaringer som fagarbeidere og møtet med utdanningen - og de opplevelser som oppstår i dette møtet - forstås her som et møte mellom to tolkningsverdener (eller figured worlds). Tolkningsverdener bygger på menneskets evne til å forme og bli formet i kollektivt oppfattede "hva hvis" verdener. For eksempel, hva om det fantes en verden kalt akademia der bøker er så viktig at mennesker sitter time etter time, borte fra venner og familie, for å lese og skrive dem? (Holland, Lachicotte, Skinner \& Cain, 1998). Disse forenklede "hva hvis" verdenene defineres av Holland et al. (1998, s. 53) som "socially and culturally constructed realm of interpretation in which particular characters and actors are recognized, significance is assigned to certain acts, and particular outcomes are valued over others". Fagarbeid som tolkningsverden kan for eksempel bestå av håndverkere (aktører) som ser verdien av - og derfor handler ut fra - at et produkt skal være ferdig til en gitt tid. Som kontrast, utdanningen som tolkningsverden der elevenes læring gjennom å arbeide med et produkt er viktigere enn selve produktet og eventuelt om det er helt ferdig på tid. En tolkningsverden er altså et sett med sosialt og kulturelt konstruerte forestillinger og antakelser som aktørene forholder seg til som om de var virkelige. I denne artikkelen åpner tolkningsverden som perspektiv opp for å utforske yrkesfaglærerstudenters opplevelse av utdanning som overgang fra fagarbeid.

Vår selvforståelse kan bli formet og endret gjennom deltakelse i tolkningsverdener (Holland et al., 1998; Urrieta, 2007) og som tolkningsverden kan utdanningen danne rammen for, og være en igangsetter av, studentenes endringsprosesser og muligheter til å forestille seg selv, eller "figure out", hvem de vil være som yrkesfaglærere. Endringsprosesser som deltakelse i tolkningsverdener kan igangsette forstås gjennom Deweys (2004) erfaringsbegrep. Dewey (2004, s. 113) hevdet at erfaringer gjør noe med oss - vi opplever noe som vi handler på, vi gjør noe med det vi opplever, og så gjør dette noe med oss i retur; "When we experience something we act upon it, we do something with it; then we suffer or undergo the consequences". Fordi erfaringer gjør noe med oss kan bearbeiding av erfaringer i utdanningen være slitsomme prosesser som griper inn i tidligere erfaringer - forstått som fagarbeiderens tolkningsverden.

\section{Metodisk tilnærming}

Datamaterialet for artikkelen bygger på deltagende observasjon og seks fokusgruppeintervju med yrkesfaglærerstudenter i 2015 og 2016 ved en yrkesfaglærerutdanning i Norge. Dette er en avgrenset, kvalitativ studie som har undersøkt studenter på andre året av bachelorprogrammet. Studien peker på faktorer av betydning, men gir ikke oversikt over feltet.

Utvalget bestod av bachelorstudenter ved Restaurant- og Matfag, Kunst- og Håndverksfag, samt Teknologiske fag. De spesifikke programmene ble valgt for 
å tilstrebe et utvalg med kjønnsbalanse, uten hensikt å sammenlikne på tvers av program eller kjønn.

De deltagende observasjonene fulgte studentenes undervisning som var organisert som samlingsbasert; Restaurant- og Matfag og Design- og Håndverksfag hadde ukesamlinger (4-5 etterfølgende dager) etterfulgt av en periode på noen uker med selvstudium eller praksis i skole eller bedrift, og studentene på Teknologiske fag møttes på fredager fordelt utover semesteret. De deltagende observasjonen fulgte $i$ all hovedsak profesjonsfaget. De samme studentene ble fulgt over et år, 120 timer totalt. Det var mellom 23 og 28 studenter i hver av programmene.

Den primære hensikten med deltagende observasjon var å bli kjent med feltet (Hatch, 2002), og samme observasjonstilnærming ble anvendt for alle program. Observasjonene åpnet opp for å danne et bilde av undervisningen og studentene i undervisningen. Temaet "overgangen fra fagarbeider til yrkesfaglærer" guidet fokuset for observasjonene sammen med åpne spørsmål som, "Hva skjer her?"; "Hvilke temaer - utfordringer og problemer - sirkulerer i klasseromsdiskusjonen?"; "Hva gjør yrkesfaglærerstudenter og faglærere i klasserommet?". Dette åpnet opp for å utforske hvordan undervisningen møter fagarbeidere i overgangen til læreryrket. Observasjonsdataene inkluderer også uformelle feltsamtaler med yrkesfaglærerstudenter og faglærere. De deltagende observasjonene og feltsamtalene tilførte innsikt $i$ et komplekst felt og en viktig kontekstforståelse som også bidro til å sette studentenes beskrivelser (fra fokusgruppeintervjuene) inn i en større forståelsesramme. Observasjonsdataene tok form som detaljerte, håndskrevne feltnotater som beskrev diskusjoner i klasserommet, handlinger og kontekst. De transkriberte notatene utgjorde 105 sider totalt.

Fokusgruppeintervjuene ble gjennomført etter observasjonene. Intervjuguiden ble utledet gjennom tidlige analyser av observasjonene. Deltakere ble rekruttert gjennom faglærerne som henvendte seg til klassen og utvalget består dermed av de studentene som responderte på invitasjonen. Hensikten var å rekruttere yrkesfaglærerstudenter med ulik erfaring fra det å være lærere, for å søke å speile studentgruppen. Studentene ble informert både skriftlig og muntlig om anonymitet samt hensikten med fokusgruppeintervjuet. Totalt 28 yrkesfaglærerstudenter deltok, jevnt fordelt på seks grupper, to grupper fra hvert program. Studentene hadde fra 5 til 25 års erfaring fra fagarbeid og fra ingen til 13 års erfaring som lærere i skolen. Hvert intervju varte ca. en time og ble transkribert ordrett. Fokusgruppeintervjuene tok en interaktiv form hvor studentene diskuterte temaene seg imellom - var både enig og uenig, og utfylte hverandres utsagn - som ga tilgang til studentenes eget språk (Wilkinson, 1998). Navnene som er brukt i presentasjonen av funnene er fiktive.

Første steg av analysen var en tematisk analyse av observasjonene og intervjuene for å identifisere utsagn om opplevelser av utdanning som overgang fra fagarbeideryrket, såkalt biografisk koherens (Smeby \& Heggen, 2014). Disse utsagnene bar preg av metaforer og kontraster, som hovedsakelig kom til uttrykk i 
intervjuene. Dermed ble primært data fra fokusgruppeintervjuene anvendt i de videre stegene av analysen.

I andre steg av analysen ble studentenes bruk av metaforer og kontraster analysert. Metaforene ble analysert ved hjelp av tolkningsverden (figured world). En tolkningsverden er et sett med konstruerte forestillinger eller antakelser, som kan forstås som "regler" eller "retningslinjer" om verden, som deltakerne forholder seg til som om de var virkelige (Hatt, 2007). Utdanning som overgang blir her forstått som en tolkningsverden - en verden i seg selv som krever noe særegent. Tolkningsverdener signaliseres gjerne av metaforer (Gee, 2011) og metaforene ga et innblikk i hva studentene assosierer med utdanning som overgang, samt tilgang til å utforske hvordan denne tolkningsverdenen konstrueres og oppleves. Metaforer brukes også når det snakkes om noe emosjonelt utfordrende, eller som en måte å uttrykke noe som ellers er mer abstrakt (Cameron, 2011). Analysen av metaforene åpnet således opp for å utforske et emosjonelt aspekt ved utdanning som overgang. Metaforer skaper et stort tolkningsrom, noe som også kan utgjøre en begrensning for selve analysen.

I tredje steg ble biografisk koherens brukt til å utforske studentenes bruk av kontraster mellom tidligere erfaringer og erfaringer i utdanningen. Studentene kommer inn i utdanning med tidligere erfaringer fra å være fagarbeidere og biografisk koherens åpnet opp for å forstå hvordan studentene bruker tidligere erfaringer til å gi mening til det opplever i utdanningen. Analysen fortsatte inn i arbeidet med presentasjonen av funnene.

\section{Funn}

Analysen gir et innblikk i hva som kjennetegner studentenes opplevelse av utdanningen som overgang. Utdanningen kan utforskes som en overgang til læreryrket, men det er samtidig en overgang fra fagarbeideryrket og analysen har lagt vekt på studentenes erfaringer fra å være fagarbeidere og hvordan de som fagarbeidere opplever overgangen til høyere utdanning og erfaringer fra å være student og lærere. Et av kjennetegnene ved studentenes beskrivelser er bruk av metaforer. Metaforene synliggjøre et emosjonelt aspekt ved overgangen; fagarbeiderens møte med erfaringer i utdanningen kan forstås som noe strevsomt og emosjonelt utfordrende. Et annet kjennetegn er bruk av kontraster. Studentene gir mening til det de opplever i utdanningen gjennom å kontrastere det til deres tidligere erfaringer som fagarbeidere.

I overgangen fra fagarbeider til yrkesfaglærer blir utdanningen et mellomstadium som skal ta studentene fra den ene posisjonen i samfunnet til den andre. Utdanningen utgjør dermed rammen for selve overgangen, en ramme hvor overgangsprosesser oppstår og blir igangsatt. Overgangen (i utdanningen) er en "verden" i seg selv som krever noe særegent av studentene. En av studentene beskriver møtet med utdanningen som "å legge fra seg" det han kan: 
Som å ta av seg verktøybeltet

Dagfinn: ... men det er jo omtrent bare å ta av deg verktøybeltet og så bytte det ut med en PC og en kulepenn og så ja, det er det du legger fra deg, det er det du kan ...

Følelsen av å legge fra seg det en kan gir assosiasjoner til å gå inn i noe ukjent uten å ta med seg tryggheten som verktøybeltet, som er kjent, kan gi. Et "verktøybelte" og en "kulepenn" kan også forstås som kontraster som bringer med seg forskjellige måter å håndtere en arbeidsoppgave på - et verktøybelte kan assosieres med praktiske ferdigheter og kunnskaper og kulepennen med noe mer teoretisk. Verktøybeltet kan også symbolisere studentenes erfaringer fra å være fagarbeidere og slik sett vil utdanningen representere et brudd med tidligere erfaringer - de legger vekk erfaringene sine som fagarbeidere og bytter det ut med en motsetning, nemlig kulepennen. At utdanningen kan skape en opplevelse av et brudd med tidligere erfaringer kan også føre med seg utfordrende følelser. Per forklarer for eksempel opplevelsen av å stå i utdanningen som et "tåkehelvete":

Per: ... jeg angret veldig det første semesteret for det var et tåkehelvete uten like for min del, men så etter semesteret har gått da så begynner jeg å skjønne hvor de [faglærerne] ville første semesteret nå, men akkurat når vi begynte så syns jeg at det var helt vanvidd, men de har jo lagt en tanke bak dette her.

"Tåkehelvete" er en relativt sterk metafor som gir assosiasjoner til noe ubehagelig. Assosiasjonen til "tåke" henleder mot en opplevelse av å ikke "se klart" og kan indikere en følelse av manglende oversikt. At han i tillegg kjente på følelser som anger understreker opplevelsen av noe ubehagelig; noe en vil vekk fra. Bruken av "vanvidd" henleder mot noe som er uforståelig eller ubegripelig og som det er vanskelig å knytte mening til. Per forklarer at utover i semestrene i utdanningen begynte han å forstå mer av de prosessene han selv var en del av og dermed også at det lå en mening (en tanke) bak opplegget i utdanningen.

Noe av det Per trekker frem som særlig forvirrende i møtet med utdanningen er at, "det var ikke noe fasit, alt er riktig, men det var ikke riktig likevel, for det var en fasit". Dette gir assosiasjoner til noe forvirrende, noe som er vanskelig å gripe og en opplevelse av motsigelser. Dette kan forklare følelsen av å stå i et "tåkehelvete" - en fasit kan forstås som et holdepunkt, noe en med sikkerhet vet vil være riktig, et fravær av en slik fasit henleder mot følelser som usikkerhet og det å stå i noe ustabilt og uforståelig. Dette kan også forstås som en kontrast til fagarbeid:

Helene: helt annen tankegang [...] asså den akademiske tenkninga, du har ikke noen konkrete svar, du har ikke to streker under svaret i forhold til at skal du sette opp et hus $\mid \ldots]$, så er det noe konkret du skal gjøre ...

Nina: og så er det litt overgang i forhold til vi som håndverkere vi jobber med noe konkret, men her så svever alt oppi, og så skal du bare ta litt der og der.

Studentene forklarer at som fagarbeidere forholder de seg til noe konkret, mens det de forholder seg til i utdanningen kan forstås som en motsetning; noe som 
svever og som ikke har noe konkret svar. Det å løse en arbeidsoppgave som student - hvor det ikke er noe konkret svar, ei heller to streker under svaret og de skal forholde seg til noe svevende - krever noe annet av dem enn å for eksempel sette opp et hus. Dette kan også forstås som en kontrast mellom det konkrete og det abstrakte - hvor det konkrete, som det å sette opp et hus, kanskje har klare rammer for hva som er opplagt feil og opplagt riktig for at huset faktisk skal stå oppreist. Å håndtere noe abstrakt krever en annen måte å forholde seg til arbeidsoppgaver på.

I tillegg til følelsen av et brudd med tidligere erfaringer samt å skulle håndtere og forholde seg til arbeidsoppgaver på andre måter tar utdanningen studentene også inn en annen måte å tenke rundt fagarbeid:

Per: det var det å begynne å tenke rett og slett, før så bare gjorde du en ting: ferdig. Nå er det liksom, eller da ble det, "ja, du har gjort en ting, men hvorfor gjorde du det?", og begynne å tenke på den måten ...

Hensikten med arbeidsoppgavene er med andre ord ikke lengre (kun) å gjøre den ferdig, det er ikke "godt nok" å fullføre den. Det kreves noe mer, noe utover å gjøre den ferdig. I utdanningen blir studentene bedt om å sette det de har gjort inn i en større forståelsesramme og "hvorfor" peker således bakover mot studentenes fagarbeiderkunnskap. Per forklarer at noe av overgangen for ham var å begynne "å tenke" sett i forhold til før, hvor han "bare gjorde". Det er tenkning involvert $i$ handlingene til en fagarbeider og dermed kan en stille spørsmålstegn ved hva Per mener med opplevelsen av å "begynne å tenke". Én grunn kan være at tenkemåter oppleves for Per som en integrert del av det han gjør som fagarbeider og derfor tenker han ikke over at han tenker. Nina og Siw diskuterer noe av det samme. De snakker om erfaringer fra lærerpraksisen og peker på at en av forskjellene mellom den og fagarbeid er nettopp å skulle forklarer hvorfor, "at du hele tiden skal begrunne ting eller kunne forklare alle mulig typer løsninger" (Nina). Da jeg spør hvorfor dette er en forskjell til fagarbeid svarer Siw at som fagarbeider, "kan du gå på instinkt". Studentene utfordres altså til å sette fagarbeid inn i en teoretisk forståelsesramme og bli kjent med de antakelsene som ligger til grunn for fagarbeidet.

I alle fokusgruppeintervjuene diskuterer studentene hvilken betydning og verdi de opplever at utdanningen har for dem og noen syns det er vanskelig å forstå meningen. Dette gjelder særlig de studentene som har jobbet som lærere i noen år forut for utdanningen. For eksempel tillegger Wilhelm verdien han som lærer har for sine elever til fagarbeiderkunnskapene og det at han, "er en arbeidskar du, er ikke en lærer". Noe av verdien han tilskriver det å være en arbeidskar er at, "du har ikke lest deg til det; du har prøvd det" (Wilhelm). Dermed kan det stilles spørsmål rundt hvilken verdi han tillegger lærerkompetansen; å tillegge lærerkompetansen liten verdi kan kanskje være med på å skape en barriere for 
utviklingen av hybrididentiteten som yrkesfaglærer. Noen av studentene beskriver også det å stå i utdanningen som noe påtvunget. Sitatene under er hentet fra to forskjellige fokusgruppeintervju:

\begin{abstract}
Ingvild: jeg føler gjennom studiet blir det skapt en overgang, ellers så hadde det vært ganske så naturlig, men nå er det litt forvirrende, det blir liksom holdt mellom de to tingene akkurat nå [...] jeg har forestilt [meg] at jeg kunne bare gå fra det ene til det andre, men plutselig "nei du må være her nà, det er den overgangsfasen", det blir påtvunget.

Kristian: jeg tenker det at når en er ferdig om tre år og ser tilbake så tenker en at "det var kanskje verdt det", når en er ferdig med ting så er det kanskje lettere å se at det var verdt det - det er det samme som å ha vært hos tannlegen; det er et helvete når det står på, men etterpå så er det jo egentlig verdt det, hvis du har tannverk ...
\end{abstract}

I likhet med Pers opplevelse av et "tåkehelvete", kommer det frem at det å stå i utdanning oppleves som påtvunget og strevsomt, som en slags kamp. Ingvild forklarer at utdanningen holder henne mellom fagarbeiderverdenen og lærerverdenen. Å bli holdt mellom noe henleder mot en følelse av å stå stille - en mellomposisjon der en verken kommer frem eller tilbake - som en slags stillstand. Denne stillstanden opplever Ingvild at hun blir holdt (fast) i og noe som blir påtvunget - overgangen er altså noe som blir skapt av, og foregår i, utdanningen og oppleves som det motsatte av naturlig. Altså noe som er konstruert. Tvang er motsetningen til frivillig og gir assosiasjoner til frarøvelse av frihet. Kristian assosierer det å stå i utdanning til tannverk. Han trekker frem at det kan godt være at han ser verdien av utdanningen når han er ferdig, men nå - når han er midt i løpet oppleves det som å være hos tannlegen hvis du har tannverk. Tannverk er noe som gjør vondt. I likhet med Per i sitatet over bruker han beskrivelsen "helvete" for å forklare hvordan det oppleves eller føles å stå i utdanningen.

Flere av studentene beskriver sitt møte med utdanningen som forvirrende. Noe av det som skaper en forvirring er de ulike rollene studentene sjonglerer mellom i utdanningen. Sitatene under er hentet fra en sekvens i et av fokusgruppeintervjuene:

Elisabeth: det som [...] forvirrer meg [...] er det å være det personen som er mel-
lom to stoler, for [...] i den utdannelsen her så [...] vet [jeg] liksom ikke hvem hatt
jeg skal ha noen ganger, for jeg har studentrollen og [...] så lærerrollen litt, for det
at vi skal tenke som en lærer og så skal vi opptre som en student og så er vi hånd-
verkere, så det blir [...] vanskelig å vite helt hvordan man skal forholde seg.

Stine: ja, det samme føler egentlig jeg, men jeg har ikke klart å komme frem til det, men det som du sier nå er ja, ja, det er det, det er litt sånn hatter som skal på og av.

Ingvild: ja, det er litt som [navn på lærer] sier sånn hattegreie, og "ta på dere hatten".

Elisabeth: ja, men [...] hvilke forventinger har de til hvilken hatt vi har på? Fordi at de forventer at vi skal tenke og opptre og handle som lærere, men de...

Ingvild og Elisabeth: ... behandler oss som studenter.

$[\ldots]$ 
Ingvild: føler tryggest som håndverker...

Stine: ja, det er der en har tryggheten sin.

Uttrykket "mellom to stoler" beskriver hvordan det oppleves å være yrkesfaglærerstudent. Det viser også tilbake til den mellomposisjonen som Ingvild beskriver at hun blir holdt fast i. Den metaforiske bruken av "stoler" peker mot de to posisjonene, fagarbeider og lærer, som studentene opplever å stå mellom. Denne mellomposisjonen er forvirrende å være i, og er kanskje karakteristisk for det å være i overgang. Metaforen "hatter" tar oss videre inn i hvordan de opplever vekslingen mellom de ulike rollene i utdanningen; student, lærer og håndverker/fagarbeider. Studentene gir inntrykk av at metaforen "hatter" er noe de har plukket opp i utdanningen. Ingvild refererer for eksempel til at faglærer bruker denne metaforen; studentene skal "ta på hatten". Dette kan være et uttrykk for hvordan utdanningen forsøker å skape et bevisst skille mellom de ulike posisjonene for studentene.

Naturlig nok representerer de tre posisjonene ulike tenke- og handlemåter, og Elisabeth uttrykker en usikkerhet rundt det å ikke vite hvilken av "hattene" utdanningen forventer at hun skal ha "på". Hvilke forventninger knyttes til lærerens måte å tenke på? Etter mange år som fagarbeidere er det nærliggende å tenke seg at forventingene knyttet til "å tenke som fagarbeider" er innarbeidet, men i takt med overgangen til en ny posisjon introduseres andre forventninger og tidligere tenke- og handlemåter (tidligere erfaringer) blir utfordret.

Siw opplever at i utdanningen må hun evne å "fange 20 ballonger". Hun kontrasterer dette til arbeidet som fagarbeider; her jobbet hun som oftest ferdig et produkt før hun begynte på neste. Dermed hadde hun gjerne en eller kanskje to arbeidsoppgaver gående samtidig. På høyskolen, derimot, følte hun "at det liksom var 20 ballonger da, som jeg skulle prøve å fange alle, ikke sant, men at jeg i virkeligheten egentlig kan håndtere en eller to ting ganske bra" (Siw). En kan se for seg hva slags følelse det å skulle fange 20 ballonger kan gi; en krevende, nesten umulig og håpløs oppgave. Sammenliknet med fagarbeid møter hun altså på forventninger om å håndtere og forholde seg til mange (svevende) ting på en gang. En viktig oppgave blir å lære seg å håndtere stresset og "det å kjenne på det stresset og på en måte innfinne seg i at":

Siw: du må faktisk vente [...] det er ikke vits i å sitte å stresse nå, men du må på en måte bare roe deg ned og så kommer den ballongen og fester seg om et halt år [...], altså sykt lang tid da.

Stress er (ofte) noe ubehagelig, noe som skaper et ubehag i kroppen. Dette ubehaget beskriver Siw at hun må kjenne på og stå i og samtidig forstå at det ikke hjelper henne å stresse fordi det som skaper stresset - å vente på at en ballong skal feste seg - vil skje en gang i fremtiden, men det er det sykt lang tid til. At noe "fester seg" kan henlede mot at en oppgave er fullført - noe som er forstått og mestret. 


\section{Diskusjon}

I denne artikkelen undersøkes det hva som kjennetegner (a) yrkesfaglærerstudenters opplevelse av YFL som overgang fra fagarbeideryrket, og (b) på hvilke måter studentene beskriver kontrastene mellom utdanningen og deres tidligere erfaringer som fagarbeidere. Studentenes bruk av metaforer og kontraster synliggjør et emosjonelt aspekt ved overgangen og at studentene gir mening til erfaringer i utdanningen gjennom å kontrastere det til deres tidligere erfaringer. Metaforer gir assosiasjoner, men er ikke tydelige beskrivelser av et fenomen, metaforbruken kan derfor indikere at studentene på andre året av bachelorprogrammet har en omtrentlig forståelse av overgangen de selv er en del av. Utdanning kan forstås som en utviklingsmekanisme - en arena der endringsprosesser blir igangsatt. Erfaringer i utdanningen tar studentene inn i følelser som ubehag, strev og håpløshet. Under diskuteres det emosjonelle aspektet ved overgang samt hvordan studentene gir mening til erfaringer i utdanningen $i$ lys av deres tidligere erfaringer som fagarbeidere.

Utdanningen plasserer yrkesfaglærerstudentene i spenningsfeltet mellom to forskjellige tenke- og handlemåter og skal utdanne dem til å håndtere motsetningene. Studentene beskriver en opplevelse av å bli holdt mellom to "verdener" og at dette er noe påtvunget og konstruert. Dette kan gi en opplevelse av å ikke ha kontroll - det er noen andre (her: utdanningen) som styrer utviklingen. Samtidig kan det å "holde" studentene i en slik mellomposisjon være et viktig poeng i overgangen - å stå mellom noe kan sette studentene i stand til å se bakover mot fagarbeid og fremover mot lærerarbeid og slik sett gi perspektiv til å sammenlikne tidligere erfaringer med nye. Likevel kan følelsen av å bli "holdt" gi en opplevelse av å stå fast i en tilstand av spenning og konflikt. En kan tenke seg at tannverk og tåkehelvete er noe en vil komme seg ut av. Samtidig skal yrkesfaglærere utdannes til å nettopp stå i spenningsfeltet mellom fagarbeid og lærerarbeid og gjennom utdanningen utvikle kompetanse til å blant annet knytte sammen to motsetningsfylte arenaer (Fejes \& Köpsén, 2014; Tapini \& Salonen, 2019). Fordi YFL er rotfestet i både håndverks- og utdanningstradisjonen står utdanningen i en særegen posisjon til å eksponere motsetningene mellom de to "verdenene" slik at de kan bli håndtert.

Studentene setter ord på hvordan de opplever utdanning som overgang ved hjelp av metaforer som for eksempel "tåkehelvete", "vanvidd", "tannverk" og "holdt i en mellomposisjon". Dette synliggjør et emosjonelt aspekt ved utdanning som overgang og gir assosiasjoner til noe strevsomt, følelsesmessig utfordrende og ubehagelig - som om det er en slags kamp de må holde ut. Metaforene gir også et innblikk i hvordan det oppleves å være en sårbar aktør. Duch` (2016) studie viser at studentene brukte "krise" for å forklare hvordan de opplevde endringer i utdanningen. "Krise" kan forstås som en unntakstilstand hvor grunnleggende element i ens livsverden blir rokket ved. Følelser - som ubehag, strev og 
krise - som utdanningen igangsetter kan forstås i lys av Deweys erfaringsbegrep (2004) og tolkningsverden. Erfaringer gjør noe med oss (Dewey, 2004) - vi opplever noe som vi handler på, vi gjør noe med det vi opplever, og så gjør dette noe med oss i retur - og kan således igangsette endringsprosesser. Fordi erfaringer gjør noe med oss kan nye erfaringer gripe inn i grunnleggende måter å forholde oss til verden og/ eller for eksempel arbeidsoppgaver på - altså, fagarbeiderens tolkningsverden. Det komplekse forholdet mellom tidligere erfaringer og utdanning (Smeby \& Heggen, 2014) kan dermed forstås som et møte mellom to forskjellige tolkningsverdener. Hvis tidligere erfaringer representerer én måte å forholde seg til verden på - ett sett med "regler" eller "retningslinjer" som fagarbeideren tar utgangspunkt i for å forstå seg selv og verden (Hatt, 2007) - og utdanningen representerer en annen, vil bearbeiding av erfaringer slik sett være slitsomme prosesser.

En tydeliggjøring av kontrastene kan være et av premissene for å skape koblinger mellom to motsetningsfylte arenaer. Studentene gir mening til erfaringer i utdanningen ved å kontrastere dem med tidligere erfaringer - å skulle "tenke akademisk" forstås for eksempel gjennom å kontrastere det til å sette opp et hus; å sette opp et hus har to streker under svaret, det er noe konkret som har en fasit, i utdanningen derimot møter de noe som svever, noe som ikke er helt mulig å gripe og som oppleves som selvmotsigende. Og videre er hensikten med arbeidsoppgaven fullført når huset står, i utdanningen er ikke dette (lengre) nok; de må vite hvorfor huset er satt opp på denne bestemte måten. Dette kan oppleves som et brudd med tidligere tenkemåter som kanskje var mer preget av å arbeide instinktivt. Samtidig peker "hvorfor" mot evnen til å reflektere over hvordan teoretisk kunnskap understøtter fagarbeid og gir således studentene tilgang til spesialkunnskapen som ligger til grunn for praksis (Alvunger \& Johansson, 2018; Wheelehan, 2015). "Hvorfor" blir dermed en videreutvikling av fagarbeiderkunnskapen og kan være med på å skape sammenheng mellom innholdet i utdanningen og studentenes tidligere erfaringer. Dette blir kanskje tydeligere for studentene utover i utdanningsløpet, samtidig kan de ha behov for hjelp til å sette det inn i en slik forståelsesramme slik at de ser verdien av å videreutvikle fagarbeiderkompetansen.

\section{Konklusjon}

I denne artikkelen ble kjennetegn ved yrkesfaglærestudenters opplevelse av YFL som overgang fra fagarbeideryrket og kontrastene mellom utdanningen og deres tidligere erfaringer som fagarbeidere utforsket. Studentene kommer inn i utdanning med tidligere erfaringer fra å være fagarbeidere og analysen viser at studentene bruker metaforer og kontraster for å gi mening til noen av sine opplevelser av utdanning som overgang. 
Metaforene synliggjør et emosjonelt aspekt ved utdanning som overgang som studentene må håndtere. Bearbeiding nye erfaringer kan være slitsomme prosesser. Å løfte frem for å håndtere slike følelser i utdanningen kan ruste studentene til å stå i spenningsfeltet mellom fagarbeid/ arbeidsliv og skole/ utdanning som yrkesfaglærere.

Utdanningen står i en særegen posisjon til å hjelpe studentene med å håndtere motsetningene mellom arbeidsliv og utdanning. Kontraster er heller ikke nødvendigvis begrensende, forskjeller kan være en viktig drivkraft for læring (Duch \& Andreasen, 2017). Tidligere studier viser at studentene tillegger sine erfaringer og kunnskaper som fagarbeidere stor verdi (Sarastuen, 2019; Nylund \& Gudmundson, 2017). Å oppleve at det de går inn i, altså utdanningen, er en kontrast til et yrkesliv og fagarbeid de tillegger stor verdi, kan samtidig skape utfordrende følelser. Likeledes som kontraster og motsetninger kan være en drivkraft for læring kan de derfor også skape barrierer. Å synliggjøre og utforske opplevde kontraster og motsetninger kan således være viktig slik at de ikke blir til et hinder for videreutviklingen av fagarbeiderkompetansen og utviklingen av lærerkompetansen.

\section{Om forfatteren}

Nora Kolkin Sarastuen har en master i pedagogikk og tar doktorgrad i profesjonsstudier ved OsloMet - Storbyuniversitetet, Senter for profesjonsstudier. Dette er tredje artikkel i doktorgradsprosjektet med tittelen "Hva kjennetegner overgangen fra å være en fagarbeider til å bli en yrkesfaglærer? Utdanning som endringsarena og overgang fra et yrke til et annet". 


\section{Referenser}

Alvunger, D. \& Johansson, V.G. (2018). Exploring recontextualization of didactic ability and vocational teacher students' professional learning through video analysis. Nordic Journal of Vocational Education and Training, $8(3), 36-56$.

Billett, S. (2011). Learning in the circumstances of work: The didactics of practice. Éducation et didactique, 5.2, 125-146.

Brandt, S.S. \& Hatlevik, I.K.R. (2003). Skreddersydd yrkesfaglærerutdanning? En undersøkelse av den treårige yrkesfaglærerutdanningen. NIFU skriftserie nr. 38/2003. Oslo: NIFU.

Cameron, L. (2011). Metaphor in spoken discourse. I: J.P. Gee \& M. Handford (Red.), The Routledge handbook of discourse analysis (s. 342-355) London: Routledge.

Chan, S. (2012). Perspectives of new trades tutors: Boundary crossing between vocational identities. Asia-Pacific Journal of Teacher Education, 40(4), 209-421.

Colley, H., James, D., Diment, K. \& Tedder, M. (2003). Learning as becoming in vocational education and training: Class, gender and the role of vocational habitus. Journal of Vocational Education \& Training, 55(4), 471-498.

Davids, A.I.R., Van den Bossche, P., Gijbels, D. \& Garrido, M.F. (2016). The impact of individual, educational, and workplace factors on the transfer of school-based learning into the workplace. Vocations and Learning, 10(3), 275306.

Dewey, J. (1916). Democracy and Education (2004 ed.). New York: Kessinger Publishing Co.

Duch, H. (2016). Professionel identitetsudvikling gennem uddannelse til erhvervsskolelærer i en empirisk undersøgelse på en diplomuddannelse. Nordic Journal of Vocational Education and Training, 6(1), 14-31.

Duch, H. \& Andreasen, K.E. (2017). VET Again: Now as a VET Teacher. International Journal for Research in Vocational Education and Training, 4(3), 289305.

Eraut, M. (2004). Transfer of knowledge between education and workplace settings. I: H. Rainbird, A. Fuller \& A. Munro (Red.), Workplace learning in context (s. 201-222). London: Routledge.

Esmond, B. \& Wood, H. (2017). More morphostasis than morphogenesis? The 'dual professionalism' of English further education workshop tutors. Journal of Vocational Education \& Training, 69(2), 229-245.

Fejes, A. \& Köpsén, S. (2014). Vocational teachers' identity formation through boundary crossing. Journal of Education and Work, 27(3), 2652-283.

Farnsworth, V. \& Higham, J. (2012). Teachers who teach their practice: The modulation of hybridised professional teacher identities in work-related 
educational programmes in Canada. Journal of Education and Work, 25(4), 473505.

Gee, J.P. (2011). An introduction to discourse analysis: Theory and method ( $3^{\text {rd }}$ ed). New York: Routledge.

Green, A. (2015). Teacher induction, identity, and pedagogy: Hearing the voices of mature early career teachers from industry background. Asia-Pacific Journal of Teacher Education, 43(1), 49-60.

Hatch, A.J. (2002). Doing qualitative research in education settings. Albany, NY: State university of New York press.

Hatlevik, I.K.R. \& Havnes, A. (2017). Perspektiver på læring i profesjonsutdanninger: Fruktbare spenninger og meningsfulle sammenhenger. I: S. Mausethagen, \& J-C. Smeby (Red.), Kvalifisering til profesjonell yrkesutøvelse (s. 191-203). Oslo: Universitetsforlaget.

Hatt, B. (2007). Street smarts vs. book smarts: The figured world of smartness in the lives of marginalized, urban youth. The Urban Review, 39(2), 145-166.

Heggen, K. \& Raaen, F.D. (2014). Koherens i lærerutdanninga. Norsk pedagogisk tidsskrift, 98(1), 3-13.

Heggen, K. \& Smeby, J-C. (2012). Gir mest mulig samanheng også den beste profesjonsutdanninga? Norsk pedagogisk tidsskrift, 96(1), 4-14.

Holland, D., Lachicotte, W., Skinner, D. \& Cain, C. (1998). Identity and agency in cultural worlds. Cambridge, MA: Harvard University Press.

Köpsén, S. (2014). How vocational teachers describe their vocational teacher identity. Journal of Vocational Education and Training, 66(4), 194-211.

Loeb, I.H. \& Gustavsson, S. (2018). Editorial: Challenges and development in and of vocational teacher education. Nordic Journal of Vocational Education and Training, 8(3), iii-x.

Nylund, M. \& Gudmundson, B. (2017). Lärare eller hantverkare? Om betydelsen av yrkeslärares yrkesidentifikation för vad de värderar som viktig kunskap på Bygg- och anläggningsprogrammet. Nordic Journal of Vocational Education and Training, 7(1), 64-87.

Page, D. (2013). Recruitment and transition of construction lecturers in further education: The perspective of middle managers. Educational Management Administration $\mathcal{E}$ Leadership, 41(6), 819-836.

Robson, J., Bailey, B. \& Larkin, S. (2004). Adding value: Investigating the discourse of professionalism adopted by vocational teachers in further education colleges. Journal of Education and Work, 17(2), 183-195.

Rokkones, K.L., Landro, J. \& Utvær, B.K. (2018). Bachelorutdanning for yrkesfaglærere, i et historisk og utviklingsorientert perspektiv. Nordic Journal of Vocational Education and Training, 8(3), 141-159.

Sarastuen, N.K. (2019). From vocational worker to vocational teacher: A study of identity transition and loss. Journal of Vocational Education and Training. DOI: 10.1080/13636820.2019.1607533 
Smeby, J-C. \& Heggen, K. (2014). Coherence and the development of professional knowledge and skills. Journal of Education and Work, 27(1), 71-91.

St.meld. 48 (1996-1997). Om Lærarutdanning. Oslo: Kyrkje-, utdannings- og forskingsdepartementet.

Tapani, A. \& Salonen, A.O. (2019). Identifying teachers' competencies in Finnish vocational education. International Journal for Research in Vocational Education and Training, 6(3), 243-260.

Urrieta, L.Jr. (2007). Identity production in figured worlds: How some Mexican Americans become chicana/ o activist educators. The Urban Review, 39(2), 107-116.

Viskovic, A. \& Robson, J. (2001). Community and identity: Experiences and dilemmas of vocational teachers in post-school contexts. Journal of In-Service Education, 27(2), 221-236.

Wenström, S., Uusiautti, S. \& Määttä, K. (2018). “The Force that keeps you going": Enthusiasm in vocational education and training (VET) teachers' work. International Journal for Research in Vocational Education and Training, 5(4), 244-263.

Wheelahan, L. (2015). Not just skills: What a focus on knowledge means for vocational education. Journal of Curriculum Studies, 47(6), 750-762.

Wilkinson, S. (1998). Focus group methodology: A review. International Journal of Social Research Methodology, 1(3), 181-203. 